\title{
Medya ve Diğer Dış Etkenlerin Gençlerin Satın Alma Davranışları Üzerindeki Etkisi
}

\section{The Effect of External Factors on Purchasing Behaviours of The Young}

\author{
Mustafa İnce, ${ }^{\mathrm{a}^{*}}$ Mevlüt Can Koçak ${ }^{\mathrm{b}}$ \\ àDoç. Dr, Karabük Üniversitesi, İletişim Fakültesi, Gazetecilik Bölümü, Karabük/Türkiye. \\ ORCID: 0000-0001-8058-1076 \\ bÖğr. Gör.Karabük Üniversitesi, Safranbolu Meslek Yüksek Okulu, Safranbolu-Karabük/Türkiye. \\ ORCID:0000-0002-9496-0541
}

\section{MAKALE BİLGİSI \\ Makale Geçmişi: \\ Başvuru tarihi: 04 Şubat 2019 \\ Düzeltme tarihi: 20 Mayıs 2019 \\ Kabul tarihi: 29 Mayıs 2019}

\section{Anahtar Kelimeler:}

Satın Alma Davranışı

Dişetken

Çevre Faktörü

Gençler

\section{A R T I C LE INFO}

\section{Article history:}

Received 04 February 2019

Received in revised form 20 May 2019

Accepted 29 May 2019

\section{Keywords:}

Purchasing Behavior

External Factor

Environmental Factor

Youth
ÖZ

İnsanların satın alma davranışlarını etkileyen pek çok parametre bulunmaktadır. Bunlar arasında en baskın olanı șüphesiz doğrudan tecrübedir. Ancak, özellikle gençlerin, satına alma davranıșları da dahil çoğu eylemleri tecrübeye dayanmamaktadır. Onun yerine kişinin yakın çevresinin fikirleri ve deneyimleri kararlarında etkili olabilmektedir. Satın alma davranışlarında optimum karar vermeyi engelleyecek veya farklı tercihlere gerekçe olabilecekbaşka unsurlar da bulunmaktadır. $\mathrm{Bu}$ çalışmanın amacı, bireyin yakın çevresi ile firmaların reklam, promosyon, kampanya vb. çalışmaları dahil dış etkenlerin, gençlerin satın alma davranışları üzerindeki etkisini belirlemeye çalışmaktır. Çalışmada elde edilen veriler, yüz yüze görüşmeye dayalı anket tekniğiyle elde edilmiştir. Araştırma sonuçlarında; kampanyaların gençlerin satın alma davranışlarında önemli etkisinin olduğu, erkeklerin markaya daha fazla önem verdiği, kadınların çevrelerinden gelen eleştirileri erkeklere oranla daha fazla dikkate aldığı ortaya çıkmıştır.

\section{A B S T R ACT}

There are many parameters that affect the purchasing behavior of people. The most dominant of these is undoubtedly direct experience. However, most of the actions of young people, including procurement behaviors, are not based on experience. Instead, ideas and experiences of the person's immediate surroundings can be effective in their decisions. There are other factors that may prevent optimal decision-making on purchasing behaviors or lead to different preferences. The aim of this study is to determine the effect of external factors like advertisement, promotion, campaign of companies 'including work activities on purchasing behaviors of young people. In the research results; it has been found that campaigns have a significant impact on the purchasing behavior of young people, men give more importance to the brand, and women pay more attention to criticism that come from their environment than men.

\section{Giriş}

Tüketim veya tüketmek, en basit anlamıyla bir şeyleri kullanıp bitirmek, yok etmek anlamına gelmektedir. Bu eylemi gerçekleştiren kişi ise tüketici olarak adlandırılmaktadır (Güzel, İpek ve Yılmaz, 2018: 11). Tanımı ve açıklaması basit olsa da tüketim kavramı psikolojik, ekonomik, sosyolojik vb. pek çok yönü bulunan oldukça karmaşık bir eylemdir. Şüphesiz ki tüketim eylemi bir tüketiciyle birlikte var olur ve öyle gerçekleşir. Satın alma davranışı olarak adlandırılan bu durum kişiden kişiye, toplumdan topluma değişiklik gösterir. Kişi (tüketim-satın alma) eylemini gerçekleştirmeden önce ve tüketim eylemi sırasında bir takım bilişsel değerlendirmelerde bulunur. Hatta bu değerlendirme kimi zaman satın alma eylemi gerçekleştirildikten sonra da devam eder. Aslında temel sorun bu davranışların gerçekleştirilmesindeki bilgi ve bilinç düzeyidir. Burada önemli olan unsurlardan biri de kişinin satın alma davranışları üzerinde nelerin belirleyici olduğudur.

Bireyler her zaman sadece ihtiyaçları olduğu için tüketmezler ya da satın alma eylemini gerçekleştirmezler. Tüketim ile

* Sorumlu yazar/Corresponding author.

e-posta: mustafaince@karabuk.edu.tr 
mutluluk, tatmin olma, haz duyma arasında bir bağlantı vardır ve bireyin bilişsel değerlendirmeye ihtiyacı da bu noktada ortaya çıkar. Teknoloji, sosyal çevre, kişisel özellikler, psikolojik durum, ekonomik koşullar, hatta iklim, coğrafya gibi pek çok faktör bireyin iç dünyasında farklı yansımalara neden olur. Kişiden kişiye farklılık gösteren bu iç dünyadaki yankılanmalar farklı tüketim kararlarını ortaya çıkarır. Kişilerin satın alma kararlarındaki etmenler sadece bireyi ilgilendiren bir durum olmanın ötesinde ekonomi, pazarlama, stratejik yönetim, davranış bilimi, siyaset, hukuk gibi birçok konuyu ilgilendirmektedir. (Özsungur, 2017:118) Bireyler, sosyal bir varlık olarak çevresel faktörlerden, farklı karakteristik özelliklere sahip olması hasebiyle içsel dünyasıyla kurduğu duygusal ve bilişsel bağ nedeniyle de ruhsal faktörlerden etkilenir. Böylece hem iç hem de dış nedenler bireylerin satın alma davranışlarında rol oynarlar.

Dış etkenlerin gençlerin satın alma davranışları üzerinde etkisini belirlemek üzere hazırlanmış olan bu çalışmada; bireylerin bilişsel değerlendirmeleri, çevresel faktörlerin kararlarındaki etkisi ile firmaların, bireylerin iç dünyasını dikkate alarak hazırladıkları tüketime yönlendirici-cezbedici çeşitli faaliyetlerin etkisine yer verilmiştir.

Günümüzün tüketim öznesi konumunda bulunan gençler özellikle hedeftedir. Sanayileşmeyle birlikte artan seri üretim ve arz-talep dengesi hem üreticileri hem de hükumetleri farklı politikalara başvurmaya zorlamış, üretilen mal ve hizmetlerin bir an önce tüketilmesi için arayışa sokmuştur. $\mathrm{Bu}$ arayış, üretim kaynaklarını ve yönetimleri kitle iletişim araçlarına ulaştırmıştır. Gazete ve televizyondan sonra, egemen kitle iletişim aracına dönüşen internet, bugün tüketim toplumunu yönlendirmede oldukça etkin bir konuma gelmiştir. $\mathrm{Bu}$ bağlamda medyanın, bilhassa yeni medyanın tüketim olgusu üzerindeki rolü artmıştır. Baudrillard'ın belirttiği gibi, artık ihtiyaçlar medya tarafından belirlenmekte, neyin ihtiyaç olduğunu düşünecek zamanı bulamayan tüketici, önüne sunulan alternatiflere 'evet-hayır' cevabından birisini verebilecek kadar bir zamanı ancak bularak, bilinçsiz bir şekilde cevaplar üretmektedir (Baudrillard. 2004: 154). Baudrillard tüketim toplumu olarak betimlediği günümüz toplumunda, gerçek ihtiyaçlar ile sahte ihtiyaçlar arasındaki ayrımın ortadan kalmış, bireyin, tüketim mallarını satın almanın ve bunları sergilemenin toplumsal bir ayrıcalık ve prestij getirdiğine inandırılmıştır. (Tükel, 2014: 2)

Böylesi bir ortamda tüketmek birey için adeta bir zorunluluğa dönüşür. Postmodern tüketici, günlük mutluluk peşinde koşan, anında tatmin isteyen, ihtiyacının tatminini ertelemeyen, gelecek için bugünü feda etmeyen, geçmiş ve geleceği içerecek biçimde denemeyi büyük bir arzuyla isteyen, içerik yerine biçime daha çok ilgi duyabilen, hazcı yanı öne çıkan, kendisini tüketime hazır bir imaj haline getirmiş tüketicidir (Featherstone, 2005: 144).

Tam da bu koşullarda mobil telefonlar (akıllı telefonlar), interneti ve sosyal medyayı da kapsayan, tüketicinin taleplerini karşılamak üzere yapılandırılmıştır. "Günümüzde milyonlarca insan, internet üzerinden alışveriş yapmakta; giysileri denemeden, parfümleri koklamadan, sebze-meyveyi dokunmadan almaktadır. Tüketim sadece maddesel de değildir; arkadaş bulmak, sohbet etmek, çeşitli aktivitelere katılmak, hatta evlenmek de internet üzerinden, fazla emek vermeden, kolay ve hızlı bir şekilde yapılabilmektedir. $\mathrm{Bu}$ anlamda günümüz tüketim toplumlarında en çok etkilenen bireyler genç kuşaktan çıkmaktadır.” (Tükel, 2014: 3)
Teknolojiyi, interneti ve dolayısıyla da sosyal medyayı günlük yaşamlarının bir parçası haline getiren gençler için, artık tüketim de günlük hayatın akışı içinde olağan bir faaliyet olarak değerlendirilmektedir. $\mathrm{Bu}$ nedenle gençlerin tüketim davranışlarının yakından izlenmesi, bu davranışların nedenlerinin araştırılması ve meselenin çözümüne katkı sağlaması açısından önem taşımaktadır.

\section{Satın Alma Bağlamında Bireyin Davranışlarını Etkileyen Faktörler}

Bir yandan kitle iletişim araçlarının çeşitlenmesi ve yaygınlaşmasıyla ortaya çıkan modern faktörler öte yandan günlük yaşantımızın en önemli parçası olan ve sosyal çevreye dayanan geleneksel faktörler bireylerin satın alma davranışlarında temel belirleyici unsurlardandır. Bununla birlikte satın alma karar sürecinde tüketicinin içinde bulunduğu aile yapısının, gelir düzeyinin, toplumdaki rol ve statüsünün, ait olduğu sosyal sınıfın da etkili olduğunu unutmamak gerekmektedir. (Aydın, 2007: 105). Çok geniş bir değerlendirme alanına sahip olan bu faktörlere burada ana hatlarıyla değinilecektir.

\subsection{Sosyal ve Çevresel Faktörler}

Kişilerin satın alma kararında hangi faktörün ne derecede etkili olduğunu kesin olarak belirlemek güçtür. Çünkü her bireyin kendi kişisel ve karakteristik özelliklerinin ve bunların kişinin iç dünyasına yansımalarının tespiti neredeyse imkânsızdır. Ancak, satın alma karar sürecine etki eden genel sosyal faktörlerin tüketicinin içinde bulunduğu aile yapısına, toplumdaki rol ve statüsüne, ait olduğu sosyal sınıfa göre şekillendiği kabul edilmektedir. (Aydın, 2007:105). Tüketicinin satın alma karar süreci neredeyse tüm pazarlama kitaplarında beş aşamalı olarak değerlendirilmektedir. İhtiyacın farkına varılmasıyla başlayan süreç satın alma sonrası tatmin veya tatminsizlikle sona ermektedir. Ancak yine de bu aşamaların hepsi yukarıda bahsettiğimiz gibi tüketici davranışlarını etkileyen sosyal, psikolojik ve kişisel faktörlerle birlikte düşünülmelidir (Mucuk, 2009: 83).

Tüketiciler, seçici bir davranışla çevrelerindeki bilgiler arasından bazılarına daha fazla önem vermekte ve kendilerine göre anlamlı bir çerçeve kurmaktadırlar. Tüketici, sorununun ne olduğunu (neye ihtiyacı olduğunu) algıladığında bunu çözmek için güdülenir. Güdülenme, bireyin çevresinden seçtiği/edindiği bilgilerin ve kurmuş olduğu çevrenin etkisi altındadır. Bir bireyin nasıl güdülendiği birçok etmene bağlı olmakla birlikte son yıllarda geliştirilen yeni bakış açıları güdülemeyi; 'bilgi edinme', 'iletişim' ve bunların sonucunda edinilen bilgiler 1şı̆̆ında 'anlam çıkarma' şeklinde açıklamaktadır. Böylece tüketici bir 'sorun çözücü' ve 'bilgi işlemci' olarak kabul edilmektedir (Aslan, 2003: 85). İhtiyacın belirlenmesi ve güdülenme aşamasından sonra tüketici bu 'sorununa' çözüm bulmak için seçenekleri belirler ve bilgi toplamaya başlar. $\mathrm{Bu}$ arayış, bellekteki bilginin güdülenmiş olarak aktif biçime getirilmesi ya da çevreden bilgilerin edinilmesi demektir. Bu aşamada, aileye danışma, komşu, arkadaş gibi yakın çevreyi gözlemleme, reklamları seyretme, mağazaları dolaşma, satış elemanları ile görüşme vb. hepsi birer bilgi kaynağıdır ve tüketici bunları kendi önem derecesine göre dikkate alır ve güvenir (Odabaşı ve Barış, 2007: 358-359). Gençlerin tüketim davranışlarını etkileyen sosyo-kültürel faktörler üzerine yapılan bir araştırmada satın alma davranışı üzerinde ailenin etkisi araştırılmış ve aileyi referans alanların oranı \%68,6 olarak 
bulunmuştur. Arkadaş grubunun satın alma davranışları üzerinde etkili olduğunu düşünenlerin oranı \%38 olarak bulunmuştur. (Saygıl1, 2011: 439-440).

Bireylerin satın alma davranışlarında etkili olan ve satın alma kararlarında sosyal faktörler olarak değerlendirebileceğimiz, kişinin sosyal çevresini oluşturan aile fertleri, iş ve özel yaşamdan arkadaşları, kültürel çevresi, yaşıtları, ünlüler, takip ettiği fikir liderleri, etki derecelerine bağlı olarak satın alma kararlarını yönlendirmekte ve davranış üzerinde önemli bir etkiye sahip olabilmektedir (Kocagöz, 2011: 122-123).

\subsection{Kişisel ve Psikolojik Faktörler}

Kişilerin satın alma davranışlarında etkili olan faktörlerden biri de kişisel ve psikolojik faktörlerdir. İmaj çağını yaşadığımız günümüzde özellikle gençlerin satın alma kararlarında kişisel faktörlerin önemli rol oynadığı değerlendirilebilir. Durmaz, Bahar ve Kurtlar (2011:114-133) tarafından yapılan 'Kişisel Faktörlerin Tüketici Satın Alma Davranışlarına Etkisi' isimli çalışmada araştırmaya katılanların yarısına yakını yaşın, kendi beğenisinin, mesleğinin, eğitiminin ve medeni durumunun satın alma davranışında önemli olduğunu belirtmişlerdir.

Kişinin yaşı, cinsiyeti, medeni hali, eğitimi, statüsü, mesleği, geliri (ekonomik düzeyi) vb. satın alma davranışında belirleyici olan kişisel faktörler olarak sayabiliriz. "Kişinin yaşı ve hangi yaş döneminde bulunduğu onun ne tür mallara, hangi model ve stillere yöneleceği konusunda önemli etkisi vardır. Malın satılacağı pazarı değerlendirirken tüketicinin yaşı ve diğer demografik faktörler çok işe yarar. Şöyle ki, yaş tüketici nüfusunu birtakım alt kültürlere böler ve mamul, fiyat, reklam ve dağıtım stratejileri değişik tüketici gruplarının ve alt kültürlerin davranış kalıplarına göre düzenlenmektedir. Bir kişinin evli veya bekar olması; evliyse çocuğunun olup olmadığı; cinsiyeti, gelir durumu; gelir durumu; eğitim düzeyi; mesleki durumu ve hayat tarzı, satın alma kararlarını en geniş boyutlarda etkileyen kişisel faktörlerdir." (Hacıŏlu Deniz, 2011:252-253)

Kişiden kişiye değişebilen psikolojik faktörleri ise öğrenme, güdülenme, inanç, tutum, algılama, kişilik (karakter) şeklinde sıralamak mümkündür. Özellikle güdüler, kişilerin tüketim davranışlarını ortaya çıkartan, onları ihtiyaçları doğrultusunda harekete geçiren güçlerdir. "Bununla birlikte, tüketici her zaman ihtiyaçlar sonucunda tepki vererek satın alma eylemine geçmemektedir. Satın alınan ürünle birlikte tatmin edilen güdünün ne olduğu üretici firma, pazarlamacı ve reklamcı firmalar için önemli bir ipucudur. Bu ipuçlarını kullanarak üreticiler sundukları markalı ürünler ile tüketicilerin güdüleri üzerine yönelerek bastırılmış veya farkında olmadıkları güdüleri harekete geçirerek satın alma davranışına doğru yönlendirmektedirler. (Hacıoğlu Deniz, 2011:254)

\subsection{Medya ve Tüketim İlişkisi}

Medya, bir başka ifadeyle basın, ortaya çıktığı ilk zamanlardan beri haber ve bilgi vermenin ötesinde bir işlev ve fonksiyona sahip olmuştur. Giderek yaygınlaşan ve çeşitlenen medyanın bireyler ve toplum üzerindeki etkisi de artmıştır. "Medyanın yaygınlığı ve büyük kitleler üzerindeki etkisi, sürekli olarak medyadan ileti alan ve medyaya bağımlı hale gelen topluluklar oluşmasına neden olmuştur. Medyanın etkilerinin, insanlar arasında örgütlenip kültüre dönüşmesiyle de medyanın yarattığ ve Moe, 2014, 337)." Toplumlar, yarın için planlarını medyadan aldıkları iletilerle yapan, medyada okudukları etkileyici yazılarla görüşlerini oluşturan, medyada gördükleri ürünlerle evlerini döşeyen, tatillerini medyadan öğrendikleri ve ilginç buldukları yerlerde geçirmek isteyen insanlardan oluşmaktadır (Lentz, 2014, 192). İnsanlar artık medyayı, yaşamak için vazgeçilmez bir kaynak olarak kullanmaktadır." (Cereci ve Özdemir, 2015: 2-3)

Başta televizyon olmak üzere kitle iletişim araçları çok farklı yaşam tarzlarını ve değişik karakterdeki kişileri ekrana taşıyarak adeta toplum bireylerine rol model olacak kişilikler sunmaktadır. Bu (renkli) yaşam tarzına ve kişiliklere özenen bireyler ise o karakterin yerinde olmak istemekte, onun gibi yaşamayı arzulamakta ve onun davranışlarını sergileyebilmektedir. Gösterge ve imajların yeni iletişim mecralarında dolaşım içinde olması, ürünlerin olduğu gibi, kimliklerin de nesneleşip hıla tüketilmesine sebep olmaktadır. "Baudrillard, televizyon ve internet gibi araçların aşırı bir şekilde imaj ve enformasyon üretmesini, öznenin yok edilişi ile birlikte bireyin, dünyayı bu araçlar aracılığı ile sanal gerçeklikte algılanmasını eleştirmektedir. Dijital dünyada öznenin yerini nesnelerin aldığ 1 tüketim toplumunun bir izdüşümü olarak görülmektedir.” (Güzel, 2016: 87-88).

Kitle iletişim araçları bu toplumsal etkiyi elbette bir ekonomik değere dönüştürmeyi ihmal etmemiştir. Çeşitli içeriklerle ekonomik kazanca dönüşen medya iletileri, en çok da reklamlar aracılığıyla kitlelere ulaşmaktadır. "Reklam doğru bilgi üzerine kurulmuş bir satıcı fikrin hedeflenen tüketici kitleye iletilmesi ve onları amaçlanan biçimde etkileme çabasıdır." (Yüksel, 1994: 164:) Reklamın amacı, firmaların kamuoyundaki tanınmışlık ve saygınlığını göstermek için, kamuoyunun firmaya olan tavrını pozitif olarak etki etmektedir. Reklamlar sayesinde ürün satışlarındaki yükselme, bir taraftan firmanın pazardaki satışlarını artışına imkân sağlarken, diğer taraftan firmanın markalaşmasına katkı sağlar. Kitle iletişim araçları vasıtasıyla farklı tarz ve şekillerde insanlara ulaşan pazarlama maksatlı mesajlar bazen kısa vadede bazen de uzun vadede satın alma davranışlarında belirleyici olmaktadır.

Günümüzde gençler, kitle iletişim araçlarını -özellikle yeni medyayı- satın alma sürecinde önemli bir merkez olarak kabul etmektedirler. Tüketicilerin yarısından fazlası sosyal medyadaki (ürün hakkındaki) diğer tüketiciler tarafından yapılan değerlendirmeleri dikkate almakta, tüketicilerin yaklaşık yüzde $35^{\prime} \mathrm{i}$ ise sosyal medyada markaları takip etmektedir. (Bkz.: Keskin ve Baş, 2015:51-69). Burada hem bizzat medya hem de interaktif bir ortamda etkileşim imkânı bulan tüketiciler birbirlerini yönlendirebilmektedirler.

Teknolojinin gelişmesi pek çok alanda etkili olmuş, özellikle üretim sürecindeki rolü sebebiyle, toplumsal düzeydeki etkilerinin tartışılmasına yol açmıştır. Bu hususta, eleştirilerin vardığı noktalardan biri, teknolojinin tarafsız veya bağımsız bir üretici güç olarak görülemeyeceği, teknolojinin de öteki üretim etmenleri gibi kapitalist üretim biçimi içinde toplumsal ve teknik iş bölümü yapısının bir parçasını oluşturduğudur. (Öngen, 1993:312) Bu çerçevede sanayinin ürettiğini kitlelere pazarlamak için biçilmiş kaftan medyadır. "Medya popüler kültürün kapitalist ürün ve içeriklerini tanıtır, meşrulaştırır ve kanıksatır. Böylece medyada görülen/gösterilen her bir nesne ya da durum kapitalist tüketim sürecinin emtiaları olarak düşünülebilir. Reklâmlardan popüler kültür ürünü olan dizilere kadar birçok 
şeyin bireyleri tüketime teşvik ettiği söylenebilir. (Demirel ve Yeğen, 2015:125) Medyanın teknolojik gelişmelerden en fazla etkilenen alanlardan biri olduğu söylemek pekâlâ mümkündür. Üstelik yeni medyanın kitlesellikten öte, bir yandan sosyal medyaya dönüştüğü diğer yandan da mobil cihazlar vasıtasıyla bireyselleşerek 'özel' alana girdiği düşünüldüğünde (kişisel) tüketimde nasıl önemli rol oynayabileceği kolaylıkla görülebilir.

\section{Araştırma}

Tüketicilerin satın alma kararlarına son aşamaya kadar etki eden pek çok unsur bulunmaktadır. Bunlar arasında markaların pazarlama etkinlikleri de dahil, bireyin psikolojik, demografik özellikleri, sosyolojik özellikle, fiziksel çevre, ekonomik durum gibi faktörler yer almaktadır. Bir tüketim toplumu girdabında bulunan bireylerin -özellikle gençlerinsatın alma davranışlarında hangi unsurların ne derece önem taşıdığının bilinmesi, toplumsal farkındalık oluşturulmasına yönelik çalışmalar açısından büyük önem arz etmektedir. Bu araştırmanın amacı, başta gençler olmak üzere tüketicilerin satın alma kararlarında etkili olan unsurların neler olduğunu belirlemek ve bu unsurların satın alma davranışlarını etkileme düzeylerini tespit etmeye çalışmaktır.

\section{1. Yöntem}

$\mathrm{Bu}$ araştırma, genel tarama yöntemine uygun olarak hazırlanmıştır. Aynı zamanda çalışmada, bağımlı ve bağımsız değişkenler arasındaki karşılıklı ilişki taraması yapılmıştır.

\subsection{Araştırmanın Uygulaması ve Örneklem Seçimi}

Araştırmanın evreni, çalışmanın yapıldığı zamanı kapsayan dönemde, Karabük'te Karabük Üniversitesi'nde eğitim göre üniversite öğrencilerinden oluşmaktadır.Rastlantısal örneklem tekniğinin kullanıldığı çalışmaya Karabük üniversitesinden 300 kişi katılmıştır. Çalışmaya konu olan veriler ise katılımcılardan yüz yüze görüşmeye dayalı anket tekniğiyle elde edilmiştir.

\subsection{Bulgular ve Yorum}

Araştırmaya katılan üniversite öğrencilerinin sosyodemografik özellikleri, frekans analizi yardımıyla ortaya çıkarılmaya çalışılmıştır. Bu çalışmaya katılan üniversite öğrencilerinin yüzde 51,0'1 erkek, yüzde 49,0'1 ise kadındır. Sonuçlar erkekler lehine farklılık gösterse de; örneklemin cinsiyeti bakımından önemli derecede bir dengesiz dağılıma sahip değildir, çalışma analiz yapılacak düzeydedir diyebiliriz (bkz. Tablo1).

Tablo 1. Katılımcıların Cinsiyetine Göre Dağılım

\begin{tabular}{lll}
\hline Cinsiyet & Sayı & Yüzde \\
\hline Erkek & 153 & 51.0 \\
\hline Kadın & 147 & 49.0 \\
\hline Toplam & 300 & 100.0 \\
\hline
\end{tabular}

Yaş dağılımının betimleyici istatistiklerine bakıldığında en düşük 18, en yüksek 28 yaşında olan üniversite öğrencileriyle görüşüldüğü ortaya çıkmaktadır. Ankette katılanların yaş ortalaması 20,98, dağılımın standart sapması ise 1,75 olarak hesaplanmıştır (bkz. Tablo 2).
Tablo 2. Yaşa İlişkin Merkezi Eğilim İstatistikleri

\begin{tabular}{lllll}
\hline $\mathrm{N}$ & $\begin{array}{l}\text { En } \\
\text { Düşük }\end{array}$ & $\begin{array}{l}\text { En } \\
\text { Yüksek }\end{array}$ & Ortalama & $\begin{array}{l}\text { Standart } \\
\text { Sapma }\end{array}$ \\
\hline 300 & 18 & 28 & 20.98 & 1.75 \\
\hline
\end{tabular}

\subsubsection{Katılımcıların Markalardan Memnuniyet Düzeyi}

Bir markanın ürününden memnun kalmanız durumunda aynı markanın diğer ürünlerini de satılır alır mısınız? Şeklindeki soruya katılımcıların yüzde 59,3'ü alırım, yüzde 18,7'si kesinlikle alırım, yüzde 12,0'i kararsızım, yüzde 9,3'ü almam, yüzde 0,7 'si ise kesinlikle almam seklinde yanıt vermiştir. $\mathrm{Bu}$ sonuçlarında ortaya koyduğu gibi; üniversite öğrencilerinin yüzde 80'e yakın bir kısmı, bir markanın ürününden memnun olmaları durumunda aynı markanın diğer ürünlerini de satılan alabileceğini belirtmişleridir.

Tablo 3. Reklamını Gördüğünüz Bir Markanın Ürününden Memnun Kalmanız Durumunda Aynı Markanın Diğer Ürünlerini De Satın Alır Mısınız? Sorusunun Yüzdelik Dağılımı

\begin{tabular}{lll}
\hline & Frekans & Yüzde \\
\hline Kesinlik Almam & 2 & 0.7 \\
\hline Almam & 28 & 9.3 \\
\hline Kararsızım & 36 & 12.0 \\
\hline Alırım & 178 & 59.3 \\
\hline Kesinlikle Alırım & 56 & 18.7 \\
\hline Toplam & 300 & 100.0
\end{tabular}

\subsubsection{Satın Alınan Ürünlerin Yanında Verilen Hediyeler}

Bir ürünü satılan alırken yanında başka bir ürünün hediye verilmesi sizi cezbeder mi? Sorusuna katılımcıların yüzde 37,3'ü cezbeder, yüzde 28,3'ü kesinlikle cezbeder, yüzde 15,0'1 kararsızım, yüzde 18,0'1 cezbetmez, yüzde 1,3’ü kesinlikle cezbetmez yanıtını vermişleridir. Bir başka deyişle araştırmaya katılanların yarısından fazla bir ürün satın alırken yanında başka bir ürünün hediye edilmesi kendilerini cezbedeceğini belirtmiştir.

Tablo 4. Satın Alırken Yanında Verilen Hediyelerin Cezbetme Durumu

\begin{tabular}{lll}
\hline & Frekans & Yüzde \\
\hline Kesinlik Cezbetmez & 4 & 1.3 \\
\hline Cezbetmez & 54 & 18.0 \\
\hline Kararsızım & 45 & 15.0 \\
\hline Cezbeder & 112 & 37.3 \\
\hline Kesinlikle Cezbeder & 85 & 28.3 \\
\hline Toplam & 300 & 100.0 \\
\hline
\end{tabular}

Uçak veya otobüs bileti alırken puan/para kazandıran firmaları tercih eder misiniz? Sorusuna üniversite öğrencilerinin yüzde 57,3'ü tercih ederim, yüzde 23,3'ü ise kesinlikle tercih ederim şeklinde yanıt vermişlerdir. Yani araştırmaya katılanların yüzde 80,6 'sı uçak veya otobüs bileti 
alırken puan/para kazandıran firmaları tercih etmektedir.

Tablo 5. Uçak Veya Otobüs Bileti Alırken Puan Kazandıran Firmaların Tercih Edilme Durumu

\begin{tabular}{lll}
\hline & Frekans & Yüzde \\
\hline Kesinlik Tercih Etmem & 0 & 0.0 \\
\hline Tercih Etmem & 20 & 6.7 \\
\hline Kararsizım & 38 & 12.7 \\
\hline Tercih Ederim & 172 & 57.3 \\
\hline Kesinlikle Tercih Ederim & 70 & 23.3 \\
\hline Toplam & 300 & 100.0 \\
\hline
\end{tabular}

3.3.3. Özel İndirimlerin Satın Alma Davranışları Üzerine Etkisi

Ürünlerde özel indirimler yapılması satın alma davranışınızı etkiler mi? Şeklindeki soruya katılımcıların yüzde 53,3'ü etkiler, yüzde 22,7'si kesinlikle etkiler, yüzde 17,3'ü kararsızım, yüzde 6,0'1 ise etkilemez şeklinde yanıt vermiştir. Sonuç olarak özel indirimler katılımcıların satın alma davranışına etki etmektedir.

Tablo 6. Özel indirimlerin satın alma davranışı üzerine etkisi

\begin{tabular}{lll}
\hline & Frekans & Yüzde \\
\hline Kesinlik Almam & 2 & 0.7 \\
\hline Almam & 18 & 6.0 \\
\hline Kararsızım & 52 & 17.3 \\
\hline Alırım & 160 & 53.3 \\
\hline Kesinlikle Alırım & 68 & 22.7 \\
\hline Toplam & 300 & 100. \\
\hline
\end{tabular}

\subsubsection{Katılımcıların Marka Bağımlılık Düzeyi}

Katılımcıların marka bağımlılığı düzeylerini belirlemek üzere 1 ile 10 puan arasında puan vermeye yönelik bir skaladan (1= Hiç Bağımlı Değilim, 10= Çok Bağımlıyım) yararlanılmıştır. 300 üniversite öğrencisinin verdiği cevapların betimleyici istatistik analizi incelendiğinde; katılımcıların marka bağımlılık düzeyi $(\bar{x}=5.20)$ orta düzeyde olduğu görülmektedir (bkz. Tablo 7).

Tablo 7. Katılımcıların Marka Bağımlılık Düzeyi

\begin{tabular}{|c|c|c|c|c|c|}
\hline & $\mathrm{N}$ & $\begin{array}{l}\text { Hiç } \\
\text { Bağımlı } \\
\text { Değilim }\end{array}$ & $\begin{array}{l}\text { Çok } \\
\text { Bağımlıyım }\end{array}$ & Ortalama & SD \\
\hline $\begin{array}{l}\text { Katılımcıların } \\
\text { marka } \\
\text { bağımlılık } \\
\text { düzeyi }\end{array}$ & 300 & 1 & 10 & 5.20 & 1.829 \\
\hline
\end{tabular}

Katılımcıların marka bağımlılıkları kategorilendirildiğinde ise; katılımcıların yüzde 5,4'ü hiç bağımlı değil, yüzde $25^{\prime}$ i bağımlı değil, yüzde 55,7'si biraz bağımlı, yüzde 7,0'1 bağımlı, yüzde 7,0'ı çok bağımlı grupta yer almaktadır (bkz. Tablo 8).
Tablo 8. Katılımcıların Marka Bağımlılıklarına Yönelik Yanıtların Yüzdelik Dağılımı

\begin{tabular}{lll}
\hline & Sayı & Yüzde \\
\hline Hiç Bağımlı Değilim & 16 & 5.4 \\
\hline Bağımlı Değilim & 75 & 25 \\
\hline Biraz Bağımlıyım & 167 & 55.7 \\
\hline Bağımlıyım & 21 & 7.0 \\
\hline Çok Bağımlıyım & 21 & 7.0 \\
\hline Toplam & 300 & 100 \\
\hline
\end{tabular}

Üniversite öğrencilerinin cinsiyetine göre marka bağımlılık düzeylerinin farklılaştığını Tablo 9'a bakılarak söylenebilir $(\mathrm{t}=2,34 ; \mathrm{p}<, 050)$. Betimleyici istatistik sonuçları; erkelerin $(\bar{x}=5,44)$ kadınlarla $(\bar{x}=4,95)$ karşılaştırıldığında, daha yüksek marka bağımlısı olduğu sonucu ortaya çıkmaktadır.

Tablo 9. Cinsiyete Göre Marka Bağımlılık Düzeyindeki Farklılik

\begin{tabular}{|c|c|c|c|c|c|c|}
\hline Cinsiyet & $\mathrm{N}$ & Ort. & Std. S & $\mathrm{T}$ & Df & Sig. \\
\hline Erkek & 153 & 5.44 & 2.02 & 2.34 & 298 & .020 \\
\hline Kadın & 147 & 4.95 & 1.56 & & & \\
\hline
\end{tabular}

3.3.5. Katılımcıların Satın Alma Davranışları Üzerinde Çevrenin Etkisi

Araştırmanın bu bölümünde katılımcılara satın aldıkları herhangi bir ürün (parfüm, kıyafet, vb.) çevreleri tarafından eleştirilmesi durumunda o ürünü tekrar satın alıp almayacakları sorulmuştur. Bu sorunun yanıtına ulaşmak için 1 ile 10 arasında puan vermelerine yönelik bir skala $(1=$ Kesinlikle Bir Daha Satın Almam, 10= Kesinlikle Satın Alırım) oluşturulmuştur. 300 üniversite öğrencisinin verdiği cevaplar incelendiğinde, böyle bir durumda karşılaşılması durumunda katılımcıların o ürünü (parfüm, kıyafet) tekrar kullanmakta tereddüt de kalacağı sonucuna varılmıştır.

Bu sorunun yanıtlarında da görüldüğü gibi çevresel faktörler kişinin davranışları üzerine etki etmektedir. Yani memnuniyet verici sonuçlarla biten davranışlar tekrarlanırken, memnuniyet verici olmayan sonuçlarla biten davranışlar tekrarlanmamaktadır. (bkz. Tablo 10).

Tablo 10. Katılımcıların Kullandıkları Bir Ürün Çevreleri Tarafından Eleştirilmesi Durumunda Davranışları

\begin{tabular}{llllll}
\hline & $\mathrm{N}$ & $\begin{array}{c}\text { Kesinlikle } \\
\text { bir daha } \\
\text { satınalmam }\end{array}$ & $\begin{array}{c}\text { Kesinlikle } \\
\text { satın } \\
\text { alıım }\end{array}$ & $\begin{array}{l}\text { Ort } \\
\text { SD }\end{array}$ & \\
\hline $\begin{array}{l}\text { Alınan bir } \\
\text { ürün çevre }\end{array}$ & 300 & 1 & 10 & 5.0 & 1.4 \\
$\begin{array}{l}\text { tarafindan } \\
\text { eleştirilmesi } \\
\text { durumunda } \\
\text { o ürünün } \\
\text { tekrar satın }\end{array}$ & & & & 8 & 6 \\
$\begin{array}{l}\text { alınma } \\
\text { durumu }\end{array}$ & & & & & \\
\hline
\end{tabular}

Katılımcıların cevapları kategorilendirildiğinde ise; aldığım bir ürün(parfüm) çevrem tarafında eleştirilirse kesinlikle o ürünü bir daha satın almam diyenlerin oranı yüzde 2, almam 
diyenler yüzde 30,7 , ara sıra alabilirim diyenler yüzde 58,4, alırım diyenlerin oranı yüzde 4,6, kesinlikle alırım diyenler yüzde 4,3'lük grupta yer almaktadır. Yani diğer bir deyişle araştırmaya katılanların sadece yüzde 8,9'luk bir kısmı çevresinde yapılan eleştirileri dikkate almayıp, satın alma davranışını değiştirmemektedir (Tablo 11).

Tablo 11. Aldığınız Herhangi Bir Ürün Çevreniz Tarafından Eleştirilirse Tekrar Alır Mısınız?

\begin{tabular}{lll}
\hline & Sayı & Yüzde \\
\hline Kesinlikle Almam & 6 & 2 \\
\hline Almam & 92 & 30.7 \\
\hline Ara sıra Alabilirim & 175 & 58.4 \\
\hline Alırım & 14 & 4.6 \\
\hline Kesinlikle Alırım & 13 & 4.3 \\
\hline Toplam & 300 & 100 \\
\hline
\end{tabular}

Katılımcıların cinsiyetine göre ise anlamlı bir farklılaşma gözlemlenmektedir. Kadınlar $(\bar{x}=4.95)$, erkeklere $(\bar{x}=5.44)$ göre satın aldıkları bir ürün çevreleri tarafından eleştirilirse o ürünü tekrar kullanmak istememe düşüncesi daha fazladır. Yani diğer bir deyişle kadınlar, çevresel faktörlerden erkeklere oranla daha fazla etkilenmektedir (bkz. Tablo 12).

Tablo 12. Cinsiyet Göre Sizin Kullandığınız Bir Ürünü Çevreniz Tarafından Eleştirilmesi Durumunda 0 Ürünü Tekrar Kullanımıyla İlgili Soruda Anlam Farklılığg

\begin{tabular}{|c|c|c|c|c|c|c|}
\hline Cinsiyet & $\mathrm{N}$ & Ort. & Std. S. & $\mathrm{T}$ & $\mathrm{df}$ & Sig. \\
\hline Erkek & 153 & 5.44 & 2.02 & 2.34 & 298 & .020 \\
\hline Kadın & 147 & 4.95 & 1.56 & & & \\
\hline
\end{tabular}

Siz bir ürünü (parfüm) çok beğenerek almadığınız halde çevreniz o ürünü çok beğenirse davranışınız ne olur? Sorusuna yanıt bulmak amaciyla 1 ile 10 arasinda puan vermelerine yönelik bir skala $(1=$ Kesinlikle Tekrar Almam, $10=$ Kesinlikle Tekrar Alırım) oluşturulmuştur. 300 üniversite öğrencisinin verdiği cevaplar incelendiğinde; katılımcıların kendileri aldıktan sonra pişmanlık duydukları bir ürünün(parfüm), çevreleri tarafından beğenilmesi durumunda o ürünü tekrar alıp alamamakta tereddüt yaşayacaklarını belirtmişlerdir.

Tablo 13. Katılımcıların Aldıkları Bir Ürünü Kendileri Çok Beğenmedikleri Halde Çevresindeki Kişiler Beğenmeleri Durumunda Davranışları

\begin{tabular}{|c|c|c|c|c|c|}
\hline & $\mathrm{N}$ & $\begin{array}{c}\text { Kesinlikle } \\
\text { tekrar } \\
\text { almam }\end{array}$ & $\begin{array}{c}\text { Kesinlikle } \\
\text { tekrar } \\
\text { alırım }\end{array}$ & Ort. & SD \\
\hline $\begin{array}{l}\text { Aldığınız bir } \\
\text { ürünü siz çok } \\
\text { beğenmediniz, } \\
\text { çevreniz çok } \\
\text { beğenmesi } \\
\text { durumunda } \\
\text { tutumunuz }\end{array}$ & 300 & 1 & 10 & 4.13 & 1.60 \\
\hline
\end{tabular}

Katılımcıların cevapları kategorilendirildiğinde ise; kesinlikle tekrar almam yüzde 13,6, almam yüzde 49,3, ara sıra alabilirim yüzde 32,7 , alırım yüzde 2,4 , kesinlikle alırım yüzde 2,0 grubunda yer almaktadır. Araştırmanın sonucunda da görüldüğü gibi araştırmaya katılanların yaklaşık yarıya yakın kısmı (kesinlikle alırım, alırım, ara sıra alabilirim) kendisi beğenmediği halde sırf çevresi beğeniyor diye bir ürünü satın alabileceklerini belirtmişlerdir.

Tablo 14. Aldığınız Herhangi Bir Ürünü Siz Çok Beğenmediğiniz Halde Çevreniz Tarafindan Çok Beğenilirse Davranışınız Ne Olur? Sorusunun Yanıtlarının Yüzdelik Dağılımı

\begin{tabular}{lll}
\hline & Sayı & Yüzde \\
\hline Kesinlikle Almam & 41 & 13.6 \\
\hline Almam & 148 & 49.3 \\
\hline Ara sıra Alabilirim & 98 & 32.7 \\
\hline Alırım & 7 & 2.4 \\
\hline Kesinlikle Alırım & 6 & 2.0 \\
\hline Toplam & 300 & 100 \\
\hline
\end{tabular}

Katılımcıların cinsiyetine göre ise anlamlı farklılaşma gözlemlenmektedir. Araştırmaya katılan kadınlar aldıkları bir ürünü kendileri çok beğenmedikleri halde, çevreleri tarafından beğenilirse, erkeklere oranla o ürünü tekrar satın almak isteyebilmektedir.

Tablo 15. Cinsiyete Göre Alınan Bir Ürünü Siz Çok Beğenmediğiniz Halde Çevreniz Beğenirse Davranışınız Ne Olur Sorusunun Anlamlı Farklılığ 1

\begin{tabular}{|c|c|c|c|c|c|c|}
\hline Cinsiyet & $\mathrm{N}$ & Ort. & Std. S. & $\mathrm{T}$ & $\mathrm{df}$ & Sig. \\
\hline Erkek & 153 & 4.65 & 1.34 & 6.105 & 298 & .000 \\
\hline Kadın & 149 & 3.58 & 1.67 & & & \\
\hline
\end{tabular}

\section{Sonuç ve Değerlendirme}

Kişilerin satın alma kararlarını etkileyen pek çok parametre bulunmaktadır. Firmaları profesyonelce hazırlamış oldukları satış ve pazarlama stratejileri ile birlikte, bireyin psikolojik, demografik özellikleri, sosyal çevre, toplumsal normlar vb. birçok etken satın alma davranışı üzerinde etkilidir. Bir tüketim toplumu girdabında bulunan bireylerin -özellikle gençlerin- satın alma davranışlarında hangi unsurların ne derece önem taşıdığının bilinmesi, toplumsal farkındalık oluşturulması açısından büyük önem arz etmektedir.

$\mathrm{Bu}$ araştırmada, dış etkenlerin gençlerin satın alma davranışları üzerinde etkisi mercek altına alınmıştır; yapılan inceleme sonucunda katılımcıların yüzde 80'e yakını, bir markanın ürününden memnun kalmaları durumunda aynı markanın diğer ürünlerini de satın alabileceğini belirtmiştir. Yani tüketiciler bir ürün aldıkları zaman o üründen memnun kalmaları durumunda, o markaya karşı bir ilgi oluşmakta bunun bir sonucu olarak markanın diğer ürünlerine de güven oluşmaktadır. $\mathrm{Bu}$ durum markalaşmanın önemini ortaya koymaktadır. Bu bağlamda çeşitli kitle iletişim araçları vasıtasıyla kitlelere ulaştırılan reklamların ve tanıtımların (markalaşmamada) ve dolaysıyla satın alma davranışlarına etkisi noktasında ne denli önemli olduğunu ortaya koymaktadır. Markalaşmanın öneminin farkında olan özellikle global markalar- son yıllarda henüz tanınmamış ama tanınma aşamasında olan markaları bünyelerine katarak, bir 
bakıma rakipsiz olmayı hedeflemektedirler.

Araştırmada ayrıca katılımcıların önemli bir kısmı, kullandıkları herhangi bir ürünün çevreleri tarafından beğenilmemesi ve eleştirilmesi durumunda tekrar o ürünü kullanmayacağını belirtmektedir. Cinsiyet açısından ise anlamlı bir farklılaşma gözlemlenmektedir. Yani kadınlar erkeklere oranla çevresel faktörlerden daha fazla etkilenip satın alma davranışlarını değiştirebilmektedirler. Bu durumu edimsel koşullanma üzerinden de açıklanabilir. Birey negatif bir olayla karşılaşırsa aynı tutum ve davranışta bulunmayacaktır. Tüketici bir yerde negatif sonuçlar doğuran davranışlardan kaçınacaktır.

Araştırmanın bulgularına bakıldığında araştırma sorusuna cevap veren üniversite öğrencilerinin, orta düzeyde marka bağımlılı̆ına sahip olduğu görülmektedir. Cinsiyet bakımından ise anlamlı farklılık bulunmaktadır. Araştırmaya katılan erkekler kadınlara oranla daha fazla marka bağımlılığına sahiptir. Özellikle tüketim kültürü içerisinde bireylerin satın alma davranışları önemlidir. Markalar bireylerin dikkatini çekerek onları kendilerinin sadık müşterileri haline getirebilmek için oldukça fazla çaba harcarlar. Tercih ettiği markayı satın alma düşüncesi, yani bir yerde marka bağımlılı̆ğ uzun zamandır tartışılan konulardan biridir. Marka bağımlılı̆̆ öğrencileri arasında çok yaygın olduğu söylense de bu araştırmada marka bağımlılığının gençler arasında çok ta yüksek olmadığını göstermektedir.

Araştırma kapsamında özel indirimlerin satın alma davranışları üzerindeki etkisi de mercek altına alınmış; yapılan araştırmada üniversite öğrencileri üzerinde, özel indirimlerin satın alma davranışı üzerinde etkili olduğu sonucuna varılmıştır. Araştırmaya katılanların önemli bir kısmı, özel indirimlerin, onların satın alma davranışlılarını olumlu yönde etkilediğini belirtmişlerdir. Tüketiciler üzerinde, özellikle üreticilerin oluşturduğu bir takım cezbedici faaliyetler, onların satın alma davranışını harekete geçirmektedir. $\mathrm{Bu}$ araştırma, özel indirimlerin olumlu bir cezbedici faaliyet olarak değerlendirilebileceği sonucunu da ortaya koymuştur.

Araştırmaya katılanların yüzde 80,6 gibi önemli bir kısmının uçak veya otobüs bileti satın alırken puan veya para kazandıran firmaları tercih ettikleri anlaşılmaktadır. $\mathrm{Bu}$ durumun farkında olan pek çok havayolu, turizm ve seyahat firmas1, bunu bir pazarlama felsefesi haline getirmiş, kendilerini tercih eden müşterilerine bu minvalde çeşitli imkanlar sunma yolunu tercih etmişlerdir.

Sonuç olarak dış etkenlerin -özellikle gençlerin- satın alma davranışları üzerinde etkisini ortaya koyması bakımından yürütülen bu çalışma, örneklem ve sorulan soruların farklılığı bakımından bu alanda yapılan az sayıda çalışmalardan biri olması itibariyle bir farklılık göstermektedir. Gelecekte farklı bölgelerde, farklı sosyo-demografik yapılar ve farklı örneklem üzerinde yapılacak çalışmalar literatürün genişlemesine katkı sağlayacaktır.

\section{Kaynaklar}

Aslan, K. (2003), Otomobil Alımında Tüketici Davranışlarını Etkileyen Faktörler, İstanbul Ticaret Üniversitesi Dergisi, Y11 2 Say1 3, ss.83-103
Aydın, K. (2007), Uluslararası ve Küresel Pazarlamada Kültürel Etkiler, 2. Baskı, İstanbul: Nobel Yayın Dağıtım

Ayhan, A. (2009). Üniversite Gençliğinde Marka-Tüketim Bağlamında Bilinç-Biliş̧ Düzeyi, Kocaeli Üniversitesi, Sosyal Bilimler Enstitüsü Dergisi, Sayı: 26, Y11: 2009/1 (27-45 s.)

Bali, R. N. (2013). “Tarz-ı Hayat'tan Life Style'a; Yeni Seçkinler, Yeni Mekanlar, Yeni Yaşamlar", İstanbul: İletişim

Baudrillard, J. (2004). “Tüketim Toplum”u, Çev.: Hazal Deliceçaylı- Ferda Keskin, İstanbul: Ayrıntı Yayınları. Aydın, K. (2007), Uluslararası ve Küresel Pazarlamada Kültürel Etkiler, 2. Bask1, İstanbul: Nobel Yayın Dağıtım

Cereci, S. Ve Özdemir H. (2015). Medyanın Toplumsal Gelişimi: Medya Toplumları, The Journal of Academic Social Science Studies, Number: 33, p. 1-10, Spring I 2015

Demirel ve Yegen (2015) Tüketim, Postmodernizm ve Kapitalizm Örgüsü, ILLEF Dergi, 115-138.Bali, R. N. (2013). “Tarz-ı Hayat'tan Life Style'a; Yeni Seçkinler, Yeni Mekanlar, Yeni Yaşamlar", İstanbul: İletişim

Durmaz, Y., Bahar, R. ve Kurtlar M. (2011). Kişisel Faktörlerin Tüketici Satın Alma Davranışlarına Etkisi Üzerine Bir Araştırma, Akademik Yaklaşımlar Dergisi, Cilt:2 Sayı:1

Featherstone, M. (2005). "Postmodernizm ve Tüketim Kültürü”, Çev.: Mehmet Küçük, İstanbul: Ayrıntı Yayınları.Ayhan, A. (2009). Üniversite Gençliğinde Marka-Tüketim Bağlamında Bilinç-Biliş Düzeyi, Kocaeli Üniversitesi, Sosyal Bilimler Enstitüsü Dergisi, Say1: 26, Y1l: 2009/1 (27-45 s.)

Fromm, E. (2008). "Sevginin ve Şiddetin Kaynağı", (Nalan İçten, Yurdanur Salman, Çev.) 7. Baskı, İstanbul:Payel Yayınevi

Güzel, E. (2016). Dijital Kültür ve Çevrimiçi Sosyal Ağlarda Rekabetin Aktörü 'Dijital Habitus', Gümüşhane Üniversitesi Illetişim Fakültesi Elektronik Dergisi, 4 (1).

Güzel, Y., İpek, G. ve Yılmaz, Y. (2018). "Tüketici Profili ve Bilinç Düzeyi Araştırma Raporu”, Türkiye Ticaret Bakanlığı, Türkiye Tüketicinin Korunması ve Piyasa Gözetimi Genel Müdürlüğü, Ankara: Kalkan Matbaacılık, Aralık 2018

Hacıoğlu Deniz, M. (2011). Markalı Ürün Tercihlerinin Satın Alma Davranışları Üzerindeki Etkisi', Sosyal Siyaset Konferanslart / Journal of Social Policy Conferences, Say1 / Issue: 61, 243-268.

Hogg, M. A. (2007), "Sosyal Psikoloji" (Çev.: İ. Yıldız ve A. Gelmez), Ankara: Ütopya Yayınları. 
Hortaçsu, N. (2003), “Çocuklukta İlişkiler: Ana Baba, Kardeş ve Arkadaşlar”, Ankara: İmge Kitapevi

Hortaçsu, N. (2007). “Ben biz siz hepimiz: toplumsal kimlik ve gruplar arası ilişkiler”, Ankara: İmge Kitapevi

Kağıtçıbaş1, Ç. (2008), “Günümüzde Insan ve Insanlar: Sosyal Psikolojiye Giriş”, İstanbul: Evrim Yayınları

Karabulut, M. (1989) “Tüketici Davranışı: Pazarlama Yeniliklerinin Kabulü ve Yayılışı”, Genişletilmiş 2. Baskı, İstanbul: İşletme İktisadı Enstitüsü, Yayın No: 164.

Karppinen, K. ve Moe, H. (2014). "What We Talk about When We Talk about "The Market": Conceptual Contestation in Contemporary Media Policy Research". Journal of Information Policy, (4), 327-341

Keskin, S. ve Baş, M. (2015). Sosyal Medyanın Tüketici Davranışları Üzerine Etkisinin Belirlenmesi, Gazi Üniversitesi İktisadi ve İdari Bilimler Fakültesi Dergisi, Cilt 17, Say1 3 ss. 51-69

Kızılçelik, S., (2004). "Zalimler ve Mazlumlar; Küreselleşmenin İnsani Olmayan Doğası”, Ankara: Anı Yayıncilik

Kocagöz, E. (2011), "Tüketici Pazarlarl ve Tüketici Davranışı” (içinde Pazarlama İlkeleri, Ed.: Canan Ay ve Tülin Ural), 1. Baskı, İstanbul: Lisans Yayıncılık

Kozanoğlu, C. (2001). "Cilall Imaj Devri, 1980'lerden 90'lara Türkiye ve Starlarl”, İstanbul: İletişim

Lentz, B. (2014). "Building the Pipeline of Media and Technology Policy Advocates: The Role of "Situated Learning"', Journal of Information Policy, (4), 176204.

Mazlum, M. (2010). "Pazarlama Ilkeleri”, Adana: Çağ Üniversitesi Yayınları.

Mucuk, İ. (2009), “Pazarlama Illkeleri”, Geliştirilmiş 17.Basım, İstanbul: Türkmen Kitapevi
Odabaşı, Y. (2006). “Tüketim Kültürü”, İstanbul: Sistem Yayıncilik

Odabaşı, Y. ve Barış, G. (2007), “Tüketici Davranışları”, 7.Basım, İstanbul: MediaCat Kitapları.

Öngen, T. (1993) Tekelci Kapitalizm ve Sınıf Yapısı. Ankara Üniversitesi SBF Dergisi, 49 (3-4), s. 303-349.

Özsungur, F. (2017). Bilişsel Yönü İle Tüketici Satın Alma Karar Süreci Ve Global Sinıflar Teorisi, Uluslararası Ekonomi, İşletme ve Politika Dergisi, 2017, 1(2), 117148

Saygılı, A. (2011), Gençlerin Tüketim Davranışlarını Etkileyen Sosyo-Kültürel Faktörler: Sakarya Üniversitesi ve Kırgızistan Türkiye Manas Üniversitesi Örneği, Doktora Tezi,Sakarya Üniversitesi Sosyal Bilimler Enstitüsü, Sakarya.

Tarhan, N. (2010). "Güzel İnsan Modeli Ailede, Toplumda, Siyasette Değerler Psikolojisi,”, İstanbul: Timaş Yayınları

Tarhan, N. (2010). "Var mı beni anlamak isteyen? Gençlik Psikolojisi”, İstanbul: Timaş Yayınları

Tarhan, N. (2013). “Toplum Psikolojisi”, İstanbul: Timaş Yayınları

Tükel, İ. (2014). Tüketimin Yeni Aktörleri: " Y Kuşağ1". Hacettepe Üniversitesi Sosyolojik Araştırmalar EDergisi.Aslan, K. (2003), Otomobil Alımında Tüketici Davranışlarını Etkileyen Faktörler, İstanbul Ticaret Üniversitesi Dergisi, Y1l 2 Say1 3, ss.83-103

Yaman, E. (2012). "Değerler Ĕgitimi, Ĕgitimde Yeni Ufuklar”, Ankara: Akçağ Yayınları

Yaman, E. (2012). "Değerler Ĕ̆itimi, Ĕgitimde Yeni Ufuklar”, Ankara: Akçağ Yayınları

Yıldırım, Y. (2016). Tüketicinin Satın Alma Karar Sürecinde Bilgi Kaynakları ve Güvenirlikleri: Referans Grubu Olarak Yakın Çevrenin Etkisinin İncelenmesi, Akademik Yaklaşımlar Dergisi, İlkbahar 2016 Cilt: 7 Say1:1 